\title{
Parental exposure to the herbicide diuron results in oxidative DNA damage to germinal cells of the Pacific oyster Crassostrea gigas
}

\author{
Barranger Audrey ${ }^{1,2,{ }^{*}}$, Heude-Berthelin Clothilde ${ }^{3}$, Rouxel Julien ${ }^{1}$, Adeline Béatrice ${ }^{3}$, \\ Benabdelmouna Abdellah ${ }^{2}$, Burgeot Thierry ${ }^{1}$, Akcha Farida ${ }^{1,{ }^{*}}$
}

\author{
1 IFREMER, RBE-BE-LBEX, Centre de Nantes, Rue de l'lle d'Yeu, F-44311 Nantes, France \\ 2 IFREMER, RBE-SG2M-LGPMM, Station de La Tremblade, Avenue de Mus de Loup, F-17390 La \\ Tremblade, France \\ ${ }^{3}$ BOREA,UMR 7208, 57 Rue Cuvier, F-75005, Paris, France \\ *Corresponding authors : Audrey Barranger, email address : audrey.barranger@gmail.com ; \\ Farida Akcha, email address : farida.akcha@ifremer.fr
}

\begin{abstract}
:
Chemical pollution by pesticides has been identified as a possible contributing factor to the massive mortality outbreaks observed in Crassostrea gigas for several years. A previous study demonstrated the vertical transmission of DNA damage by subjecting oyster genitors to the herbicide diuron at environmental concentrations during gametogenesis. This trans-generational effect occurs through damage to genitor-exposed gametes, as measured by the comet-assay. The presence of DNA damage in gametes could be linked to the formation of DNA damage in other germ cells. In order to explore this question, the levels and cell distribution of the oxidized base lesion 8-oxodGuo were studied in the gonads of exposed genitors. High-performance liquid chromatography coupled with UV and electrochemical detection analysis showed an increase in 8-oxodGuo levels in both male and female gonads after exposure to diuron. Immunohistochemistry analysis showed the presence of 8-oxodGuo at all stages of male germ cells, from early to mature stages. Conversely, the oxidized base was only present in early germ cell stages in female gonads. These results indicate that male and female genitors underwent oxidative stress following exposure to diuron, resulting in DNA oxidation in both early germ cells and gametes, such as spermatozoa, which could explain the transmission of diuron-induced DNA damage to offspring. Furthermore, immunostaining of early germ cells seems indicates that damages caused by exposure to diuron on germ line not only affect the current sexual cycle but also could affect future gametogenesis.
\end{abstract}

Keywords : Crassostrea gigas, Oxidative stress, DNA damage, Germ cell, Pesticides 


\section{Introduction}

The living cell is constantly exposed to potentially-damaging free radical species of endogenous origin, such as those arising from normal cellular metabolism, or exogenous origin, resulting from exposure to ultraviolet radiation, ionizing radiation or xenobiotics (Evans et al., 2004). Exposure of aquatic organisms to chemical pollutants can hence promote an increase in the production of reactive oxygen and nitrogen species (ROS/RNS) (Alves de Almeida et al., 2007). When the rate of ROS/RNS production exceeds the efficiency of antioxidant defences and repair systems, an imbalance occurs in the redox status and oxidative stress can arise, leading, inter alia, to the oxidation of key cell components such as proteins, fatty acids and DNA, thereby contributing to toxicity (Sies, 1993). Among 
chemicals, certain pesticides are known to induce oxidative stress (Lushchak, 2011).

Pesticides are ubiquitous pollutants of aquatic systems. In France, 93\% of rivers are contaminated by pesticides (SoeS, 2013). In addition to inputs by rivers, pesticides used mainly for agricultural purposes can be dispersed to coastal waters through various processes, including run-offs, leaching and spray drift. Marine environments and, in particular, coastal ecosystems, are often considered as the end receptacle of chemical pollutants. Coastal areas are usually characterized by high primary production, supporting the development of numerous species, e.g. shellfish farming zones. The Pacific oyster, Crassostrea gigas (Thunberg), was introduced into France in 1966 (Grizel and Héral, 1991) and is now the most-cultivated bivalve species. With annual production reaching 82,000 tons in 2012 (FAO, 2014), France is currently Europe's leading country for oyster production. For several years, this species has been facing mass summer mortality events; the causes of these are undefined, but appear to be multifactorial and include physiological stress, infection by pathogenic organisms and environmental conditions (Dégremont et al., 2010; Huvet et al., 2010; Renault et al., 1994; Samain and McCombie, 2008). Chemical pollution by pesticides has been identified as one of the possible factors involved in this mortality phenomenon, due to their toxic effects on oysters (Akcha et al., 2012; Buisson et al., 2008; Gagnaire et al., 2007; His and Seaman, 1993; Mai et al., 2012; Mottier et al., 2014; Ochoa et al., 2012; Wang et al., 2009). In the Ebro delta (Spain), Köck et al. (2010) found a correlation between pesticide concentrations in water and shellfish flesh and episodes of mortality. Agrochemical inputs are known to display seasonal variations: in France, high pesticide concentrations have been detected in spring in a major shellfish farming zone, the Marennes Oleron basin, corresponding to the highly-sensitive oyster gametogenesis period (Burgeot et al., 2008; Munaron, 2004; Soletchnik et al., 2005). Pesticides not only have direct toxic effects on adult oysters, but also indirect trans-generational effects on their offspring (Barranger et al., 2015, 
2014; Bouilly et al., 2007, 2003). In a previous experiment conducted by our laboratory, oyster genitors in gametogenesis were subjected to short exposures (two 7-day pulses) of environmental concentrations of the herbicide diuron $\left(0.3 \mu \mathrm{g} . \mathrm{L}^{-1}\right)$. The genotoxicity of diuron was demonstrated in genitor haemocytes. Moreover, DNA damage was also detected for the first time in genitor spermatozoa (strand breaks) and in offspring (DNA aneuploidy in spat), highlighting the vertical transmission of DNA damage further to parental exposure (Barranger et al., 2014). The genotoxicity of diuron could result from oxidative stress. The oxidation of DNA by ROS/RNS can actually produce strand breaks and a variety of modified DNA bases. Base oxidation is probably the foremost source of DNA damage. Among the four normal nucleobases, guanine (Gua) is the most susceptible to oxidation due to its low oxidation potential. The interaction of $\mathrm{HO} \bullet$ (the most reactive oxygen-free radical) with DNA strand nucleobases, such as guanine, leads to the formation of C8-hydroxyguanine (8-OHGua), or its nucleoside form deoxyguanosine (8-hydroxy-2'-deoxyguanosine). 8-oxodGuo is the most abundant oxidized nucleobase found in DNA and is widely used as a marker of DNA damage, carcinogenesis and oxidative stress in humans (Halliwell and Aruoma, 1991). If it is not removed by DNA repair systems, 8-oxodGuo can result in mutagenesis by G:C to T:A transversions during DNA synthesis (Shibutani et al., 1991). Its formation has also been reported in bivalves following exposure to pollutants or exposure in the field. It has been put forward and used in ecotoxicology as an efficient marker of both oxidative stress and genotoxicity (Akcha et al., 2000a; Almeida et al., 2005; Aloisio Torres et al., 2002; Alves de Almeida et al., 2007; Canova et al., 1998; Charissou et al., 2004; Lemiere et al., 2005). Our previous results suggest that the vertical transmission of DNA damage occurs through damage to genitor-exposed gametes. In order to further our understanding of diuron genotoxicity, gonad tissue of genitors originating from our previous experiment (Barranger et al., 2014) were analyzed for the detection of 8-oxodGuo. Two different methods were used 
109 for this study. Firstly, 8-oxodGuo levels in gonad tissue were measured using high-

110 performance liquid chromatography coupled with UV and electrochemical detection (HPLC-

111 UV-ECD). In a second step, immunohistochemical detection of 8-oxodGuo was performed to

112 locate base damage to the various types of cells present in gonadal tubules and, particularly, in

113 germ line. Our results should contribute to improving understanding of diuron genotoxicity in

114 oysters and how genitor exposure can significantly impact the DNA integrity of the following

115 generation, with potential effects on oyster physiology at a population level.

116

\section{Materials and Methods}

\subsection{Genitor origin and diuron exposure}

The adult Pacific oysters (Crassostrea gigas) used for this experiment were progenies of wild oysters sampled in the Marennes-Oléron Bay (France). Oyster husbandry/broodstock conditioning, and diuron exposure were performed as described by Barranger et al. (2014). temperature $\left(8^{\circ} \mathrm{C} \pm 1^{\circ} \mathrm{C}\right)$ was gradually raised by two degrees per day for 1 week, to reach $19.8^{\circ} \mathrm{C}\left( \pm 0.3^{\circ} \mathrm{C}\right)$. Once gonad development had begun, the oysters were divided into three experimental groups: a seawater control, a solvent control and a diuron-exposed group. Three 250-L tanks were used for each experimental group, each containing 240 oysters. Two 7-day exposure periods took place at the start and mid-course of gametogenesis. Diuron - the pesticide selected for our study - is a substituted urea herbicide used in agriculture for on-land weed control. This herbicide is also used as an antifouling biocide (Thomas et al., 2001). In

130 France, its use as a phytosanitary product has been banned since 2008 (The Official Journal of 131 the French Republic no. 204 September 4, 2007), and as a biocide used in antifouling paints 132 since 2009 (The Official Journal of the French Republic - bylaw 21 August, 2008). However, 133 diuron is still the fourth most commonly-found pesticide in French rivers (SOeS, 2013) and 
134 recent studies have reported its presence in various French coastal waters (Atlantic bays,

135 estuaries and Mediterranean Sea) (Buisson et al., 2008; Caquet et al., 2013; Munaron et al.,

136 2012). The oysters were exposed to nominal diuron concentrations of 0.4 and $0.6 \mu \mathrm{g} / \mathrm{L}$,

137 respectively. However, the analysis of passive samplers (Polar organic chemical integrative

138 samplers, POCIS) used in the previous experiment showed oyster exposure to integrated

139 concentrations as low as 0.2 and $0.3 \mu \mathrm{g} \mathrm{L}^{-1}$.

\subsection{Sampling program}

141 Various gonad samples were collected after completion of genitor exposure. For HPLC-UV-

142 ECD analysis, the gonads were sampled and stored in liquid nitrogen prior to analysis. 10

143 males and 10 females were analyzed in each experimental group. For histological analysis,

144 transverse sections $(5 \mathrm{~mm})$ cut in the vicinity of gill-palp junction were fixed in Davidson's

145 solution (48 h; 10\% glycerol, 20\% formaldehyde, 30\% ethanol (95\%), 30\% sterile sea water,

$14610 \%$ acetic acid), then stored in $70 \%$ ethanol. 5 males and 5 females were analyzed in each

147 experimental group. For HPLC-UV-ECD and histological analyses, each sample/individual

148 was realized in duplicate.

\subsection{Quantification and location of oxidative DNA damage}

\subsubsection{Measurement of 8-oxodGuo levels in genitor gonads using HPLC/UV-ECD}

\section{DNA extraction}

152 For each gonad sample, DNA was extracted from 100-150 mg of gonad tissue using the

153 chaotropic NaI method derived from Helbock et al. (1998), slightly modified by Akcha et al.,

154 (2000b). The samples were centrifuged at $1,500 \mathrm{~g}$ for $10 \mathrm{~min}$ at $4^{\circ} \mathrm{C}$. Supernatants were

155 discarded and the pellets were suspended in $2 \mathrm{~mL}$ of Buffer A (320 mM sucrose, $5 \mathrm{mM}$

$156 \mathrm{MgCl}_{2}, 10 \mathrm{mM}$ Tris-HCl, $0.1 \mathrm{mM}$ deferoxamine mesylate, $1 \%$ Triton $\left.\mathrm{X}-100, \mathrm{pH} 7.5\right)$.

157 Following centrifugation $\left(1,500 \mathrm{~g}, 10 \mathrm{~min}, 4^{\circ} \mathrm{C}\right)$, the pellets were recovered and resuspended 
158 in $600 \mu \mathrm{L}$ of Buffer B (5 mM EDTA-Na2, $10 \mathrm{mM}$ Tris-HCl, $0.15 \mathrm{mM}$ deferoxamine

159 mesylate, $\mathrm{pH}$ 8). After addition of $35 \mu \mathrm{L}$ of $10 \%$ SDS, RNA digestion was performed by

160 incubation with $120 \mu \mathrm{g}$ of RNase $\mathrm{A}$ and $20 \mathrm{U}$ of RNase $\mathrm{T} 1$ for $15 \mathrm{~min}$ at $50^{\circ} \mathrm{C}$. Protein

161 digestion was performed by incubation with $600 \mu \mathrm{g}$ of protease for $1 \mathrm{hr}$ at $37^{\circ} \mathrm{C}$. The samples

162 were then centrifuged at $5,000 \mathrm{~g}$ for $15 \mathrm{~min}$ at $4^{\circ} \mathrm{C}$, and supernatants were recovered in $15 \mathrm{~mL}$

163 sterile tubes. After the addition of $1.2 \mathrm{~mL}$ of sodium iodide solution (20 mM EDTA-Na2, 7.6

$164 \mathrm{M} \mathrm{NaI}, 40 \mathrm{mM}$ Tris- $\mathrm{HCl}, 0.3 \mathrm{mM}$ deferoxamine mesylate, $\mathrm{pH} 8$ ) and $2 \mathrm{~mL}$ isopropanol, the

165 tubes were centrifuged for $15 \mathrm{~min}$ at 5,000 g. The pellets were then recovered and

166 resuspended in $2 \mathrm{~mL} \mathrm{40 \%} \mathrm{isopropanol.} \mathrm{After} \mathrm{centrifugation}\left(5,000 \mathrm{~g}, 15 \mathrm{~min}, 4^{\circ} \mathrm{C}\right)$, the pellets

167 were washed in $2 \mathrm{~mL}$ of $70 \%$ glacial ethanol and centrifuged at $5,000 \mathrm{~g}$ for $5 \mathrm{~min}$ at $4^{\circ} \mathrm{C}$.

168 Ethanol was then discarded using a pipette, and the pellets were left to dry for $1 \mathrm{hr}$ at room

169 temperature. DNA was finally resuspended in $100 \mu \mathrm{L}$ of deferoxamine mesylate $0.1 \mathrm{mM}$ and

170 left to dissolve overnight at $37^{\circ} \mathrm{C}$. DNA quantification was performed by spectrophotometry

171 at 280, 260, and $230 \mathrm{~nm}$ wavelengths using a ND1000 NanoDrop (NanoDrop Technologies,

172 Inc). After quantification, the DNA samples were stored at $-20^{\circ} \mathrm{C}$ prior to digestion.

\section{DNA digestion}

174 For each sample, $15 \mu \mathrm{g}$ of DNA were filtrated $(0.2 \mu \mathrm{m})$ and digested into 2 '-

175 desoxyribonucleosides by incubation with $5 \mathrm{U}$ of nuclease $\mathrm{P} 1$ for $2 \mathrm{hrs}$ at $37^{\circ} \mathrm{C}$. Four units of

176 alkaline phosphatase were then added for an additional 1 -hour incubation at $37^{\circ} \mathrm{C}$. The sample

177 was centrifuged $\left(5 \mathrm{~min}, 7,000 \mathrm{~g}, 4^{\circ} \mathrm{C}\right)$ and the supernatant was recovered for injection.

$178 \quad$ HPLC analysis

179 8-oxodGuo levels were determined by HPLC (Agilent 1200 series) coupled to

180 electrochemical (Coulochem III, ESA) and UV (Agilent 1200 series) detection. Separation of

181 8-oxodGuo and 2'- deoxyribosides was performed using an Ultrasphere pre-column (5C18, 
182 Interchim) and an Uptisphere column (5ODB, Interchim). Elution was performed in isocratic

183 mode using a mobile phase composed of $10 \%$ methanol and $100 \mathrm{mM}$ sodium acetate, at $\mathrm{pH}$

184 5.2. The elution flow rate was set at $1 \mathrm{~mL} \cdot \mathrm{min}-1$. The guard and measure cells were

185

186

187 respectively set at an oxidation potential of 460,150 and $380 \mathrm{mV}$. The quantification of 8oxodGuo was performed in accordance with a calibration curve previously obtained with known pmole amounts of authentic 8-oxodGuo. For a standard expression in the number of 8oxodGuo residues per $10^{6} \mathrm{dGuo}$, deoxyguanosine was also quantified by fitting a UV detector to the output of the HPLC column. The UV detector was set at a wavelength of $254 \mathrm{~nm}$. A calibration curve was also obtained for this compound within the nmole range. For the described conditions, the retention times of both 8-oxodGuo and dGuo were respectively 14 and $10 \mathrm{~min}$ at $35^{\circ} \mathrm{C}$. Each sample were analyzed in duplicate and results were expressed in number of 8-oxodGuo per $10^{6} \mathrm{dGuo}$.

\subsubsection{Immunohistochemical detection of 8-oxodGuo in genitor gonad cells}

As previously mentioned, cells naturally produce free radical species. A background level of DNA damage, e.g. 8-oxodGuo, therefore exists in all living cells (Evans et al., 2004). As immunostains are not stoichiometric, it is impossible to use immunohistochemistry such as HPLC measurement to compare 8-oxodGuo levels across control and exposed groups. Immunohistochemistry solely provides qualitative information on the location of 8-oxodGuo in the various cell types of oyster gonads.

\subsubsection{Histology}

\section{Slide preparation, gametogenesis stage and sex determination}

Each dehydrated sample was embedded in paraffin wax and several $4 \mu \mathrm{m}$ sections were cut and individually deposited on a slide for subsequent treatment. For each sample, one of the slides was stained using the Prenant-Gabe trichrome method (Gabe, 1968) to allow individual 
determination of sex and gametogenesis stage on the basis of criteria previously described by

207 Heude-Berthelin et al. (2001) for diploid C. gigas. Briefly, stage 0 corresponds to the sexual resting stage. Stage I is defined as the early developmental stage (gonial mitosis). The germinal lineage develops at stage II, whereas stage III is characterized as the ripe gonad.

\section{Immunohistochemistry with anti-8oxo antibody}

211 The slides were deparaffinized ( $2 \times 5 \mathrm{~min}$ in Roti $\left.{ }^{\circledR}-H i s t o l\right)$, immersed in methanol- $\mathrm{H}_{2} \mathrm{O}_{2} 3 \%$

$212(\mathrm{v} / \mathrm{v})$ for $30 \mathrm{~min}$ for inhibition of endogen peroxidases, rehydrated, and soaked in running water $(5 \mathrm{~min})$. They were then incubated at $37^{\circ} \mathrm{C}$ for $1 \mathrm{~h}$ with $100 \mu \mathrm{g} / \mathrm{ml}$ RNase and washed in

214 Buffer 1 (Tris $50 \mathrm{mM}, \mathrm{NaCl} 150 \mathrm{mM}$, pH 7.4) for $2 \times 5$ min. Proteins were removed from

215 DNA by digestion with proteinase $\mathrm{K}(10 \mu \mathrm{g} / \mathrm{ml}$ in Tris buffer, at $\mathrm{pH} 7.5)$ at room temperature

216 for $5 \mathrm{~min}$. To increase antibody accessibility to the antigen, a denaturation step in $1 \mathrm{~N} \mathrm{HCl}$ for

$21710 \mathrm{~min}$ was added. The slides were then rinsed in buffer 2 (Tris $50 \mathrm{mM}, \mathrm{NaCl} 150 \mathrm{mM}$, 218 gelatin $0.25 \%$, Triton X-100 0.5\%, pH 7.4) for $2 \times 10 \mathrm{~min}$ (Franco et al., 2010) and incubated 219 overnight at $4^{\circ} \mathrm{C}$ with the primary antibody 8-OHdG (15A3, Santa Cruz Biotechnology) 220 diluted (1:100) in buffer 1 . This antibody is recommended for the detection of 8-hydroxy-2'221 deoxyguanosine, 8-hydroxyguanine and 8-hydroxyguanosine. After two rinses in buffer 2, the 222 slides were incubated for $1 \mathrm{~h}$ at room temperature with horseradish peroxidase conjugated 223 polyclonal rabbit anti-mouse $\operatorname{IgG}\left(\operatorname{Dako}^{\circledR}\right)$ diluted (1:100) in buffer 1, then rinsed in buffer 1.

224 Peroxidase activity was visualized after 10 min incubation with $200 \mu \mathrm{L} \mathrm{DAB}$ (3, 3'

225 diaminobenzidine, FastDAB, Sigma- Aldrich $\left.{ }^{\circledR}\right)$ as a brown precipitate. Sections were 226 counterstained light green, then mounted in resin (Roti ${ }^{\circledR}-H i s t o k i t t$ Roth $\left.^{\mathrm{TM}}\right)$. Controls without 227 primary or secondary antibodies were also performed. Identification of labelled cells in gonad was based on Heude-Berthelin et al. (2001) and Franco et al. (2008). 
231 In order to compare 8-oxodGuo levels detected with the HPLC method, statistical tests were

232 conducted using STATISTICA (StatSoft, Inc.,version 10). Normality was checked using

233 Lilliefor's test and variance homogeneity was evaluated using Bartlett's test. When necessary,

234 raw data were mathematically transformed $(\mathrm{Ln})$ to achieve normality before proceeding with

235 an ANOVA. When significant, an a posteriori Tukey test was performed.

3. Results

\subsection{Quantitative analysis of 8-oxodGuo levels in gonad tissue}

In the control group, 8-oxodGuo levels in gonad DNA were $11.8 \pm 7.8$ and $13.0 \pm 1.2$ per $10^{6}$

dGuo in males and females respectively. In the solvent control group, 8-oxodGuo levels in males were similar to those measured in the control group $\left(12.2 \pm 4.8\right.$ per $\left.10^{6} \mathrm{dGuo}\right)$ (Figure 1A), but significantly higher in females $\left(+89 \%\right.$; $24.6 \pm 8.4$ per $\left.10^{6} \mathrm{dGuo}\right)$ (Figure $\left.1 \mathrm{~B}\right)$. Despite the sex-specific effect of the solvent, a significant increase in 8-oxo-dGuo levels was detected in both male $(+73 \%)$ and female $(+270 \%)$ gonads following diuron exposure $(\mathrm{p}<0.05)$. DNA damage was significantly higher in females than in males: $48.1 \pm 28.2$ versus $20.4 \pm 5.58$ oxodGuo per $10^{6}$ dGuo (Figure 1).

\subsection{Immunodetection of 8-oxo-dGuo in gonad cells}

248 After exposure, analysis of the gonad histological slides showed all genitors, both males and

249 females, to be at stage III, corresponding to the mature reproductive stage. Controls without 250 primary or secondary antibodies showed no specific labelling (Figure $2 \mathrm{~A}, \mathrm{~B}$ ). Of note, during 251 the methodological development of immunodetection, some slides were realized in males without RNase treatment leading to a strong immunolabelling in particular in the cytoplasm of spermatogonia (Figure $2 \mathrm{C}, \mathrm{D})$. 


\subsubsection{Male gonads}

256 In male gonads, oxidized nucleosides were detected in all nuclei of spermatogonia I (pale spermatogonia) and II (dark spermatogonia) (Figure $3 \mathrm{~A}, \mathrm{~B}, \mathrm{C}, \mathrm{D})$ and in the nuclei of few spermatocytes and spermatids (Figure $3 \mathrm{C}$ ). Immunolabelling was not systematically detected in spermatozoids in individuals and across individuals (Figure $3 \mathrm{C}, \mathrm{D}$ ). Oxidized nucleosides were also labelled in intra-gonadal somatic cells (Figure $3 \mathrm{~B}$ ) and in few haemocytes present in the gonad (Figure 3 A, D). No differences were observed in terms of cell distribution of 8oxodGuo labelling across the experimental groups.

\subsubsection{Female gonads}

264 In female gonads, oxidized nucleosides were observed in the nucleolus, nucleus and cytoplasm of young oogonia and also in nucleus of undifferentiated germ cells (putative germ stem cells) pressed against the inside of the tube (Figure 4 A, B, C), but were not detected in oocytes (Figure 4 D, E). Similarly to male gonads, immunolabelling was also observed in

268 intra-gonadal somatic cells (Figure 4 C, D, E) and in interstitial conjunctive cells (Figure 4 C).

269 No differences were observed in terms of cell distribution of 8-oxodGuo across experimental 270 groups.

\section{Discussion}

272 In this study, the levels and cell distribution of the oxidized base lesion 8-oxodGuo were

273 studied in the gonads of diuron-exposed genitor, in order to better characterize the

274 transgenerational effect observed in a previous study (Barranger et al., 2014). In bivalves, 8-

275 oxodGuo, as a marker of oxidative stress and genotoxicity, is essentially measured in gills,

276 digestive glands and mantles, but never, in our knowledge, in reproductive tissue. While

277 genotoxicity in somatic cells may have implications at the individual level, genotoxic events 278 occurring in germ cells may lead to genomic abnormalities in future generations. 
In our study, 8-oxodGuo levels in the gonads of control genitors appeared to be in the range of values reported in other bivalve tissues (Akcha et al., 2000a; Alves de Almeida et al., 2007; Charissou et al., 2004; Lemiere et al., 2005). An increase in 8-oxodGuo lesions was observed following exposure to diuron, with females shown to be more sensitive to base oxidation than males. Oxidative stress induced by diuron could be one of the mechanisms responsible for DNA damage to gonads of exposed genitors. Certain pesticides are known to induce oxidative stress via various mechanisms. For example, the herbicide paraquat (N,N'-dimethyl-4,4'bipyridinium dichloride) is known to be directly responsible for enhancing free radical generation, entering redox cycles and constantly generating ROS. Other herbicides (for example diethyldithiocarbamate, DDC) are known to be inhibitors of antioxidant enzymes, such as superoxide dismutase (SOD) and catalase (CAT) (Lushchak, 2011). In the case of diuron, both mechanisms may be involved. Bouilly et al. (2007) reported an increase in ROS production in oyster hemocytes following a 4-week exposure to 0.3 and $3.0 \mu \mathrm{g} . \mathrm{L}^{-1}$ of diuron. Moreover, diuron appears to decrease the activity of the antioxidant enzyme superoxide dismutase (SOD) in oysters further to 6 and $24 \mathrm{~h}$ exposure to $1 \mu \mathrm{g} . \mathrm{L}^{-1}$ of diuron (Luna-Acosta et al., 2012). As diuron has a low bioconcentration factor (BCF) in oysters, with values ranging from 7 to 17 (Luna-Acosta et al. 2012, Buisson et al. 2008), its biotransformation in oyster can play a primordial rule in its ability to induce an oxidative stress.

High levels of 8-oxodGuo induced by acetonitrile, the solvent used for diuron dissolution, were also observed in females. Acetonitrile is known to enhance oxidative stress in certain organisms (Kirankumar et al., 2013) and is considered as the most toxic solvent used in ecotoxicological studies (Barahona-Gomariz et al., 1994). Female genitors appeared more prone to oxidative stress than males with regards to 8-oxodGuo levels in gonad tissue. Sex differences in oxidative stress response have already been observed in humans, with higher sensitivity shown by men or women according to the exposure context (Brunelli et al., 2014; 
304 Kamhieh-milz and Salama, 2014). Similar differences have also been observed in fish. In Nile

305 Tilapia, following paraquat exposure, males have been shown to have higher SOD activity 306 than females (Figueiredo-Fernandes et al., 2006). Despite the fact that female oysters showed

307 higher levels of 8-oxodGuo, it is interesting to note that immunohistochemistry analysis in 308 gonad revealed the cell distribution of oxidized nucleosides to be far more limited than in 309 males. Although 8-oxodGuo was only present in young oogonia and in some undifferentiated 310 germ cells pressed against the inside of the tube (Figure 4), it was detected in all the germ 311 lineage in male. Because in both sex, labelled early germ cells could correspond at least in 312 part to germ stems cells (which remain poorly characterized in this alternative 313 hermaphrodite), diuron exposure could affect not only the gametogenesis in course but also

314 future reproductive cycles. Of note, the results obtained in males corroborated previous

315 findings using the comet assay in sperm from the same genitors (higher levels of DNA strand 316 breaks) (Barranger et al., 2014). Spermatozoa of exposed genitors were potentially involved 317 in the transmission of damaged DNA, leading to the negative impact observed on oyster 318 recruitment (decreased hatching rate, higher levels of larvae abnormalities and reduced larvae 319 growth).

320 Little is known about DNA damage in germ cells and gametes of aquatic invertebrates. In 321 Crassostrea gigas, Akcha et al. (2012) showed that in vitro exposure to diuron leads to DNA 322 strand breaks in spermatozoa from concentrations as low as $0.05 \mu \mathrm{gL}^{-1}$. The sensitivity of 323 oyster sperm to herbicides was confirmed by Mai et al. (2014) following exposure to 324 metolachlor, with genotoxicity observed from concentrations of $0.01 \mu \mathrm{gL}^{-1}$. In the freshwater 325 crustacean Gammarus fossarum, Lacaze et al. (2011) also found spermatozoa to be clearly 326 more sensitive to genotoxicants than oocytes. Moreover, they observed that after 5-day 327 exposure to methyl methanesulfonate (MMS) and 4-day recovery, spermatozoa showed no 328 decrease in DNA damage, contrary to oocytes, in which DNA damage was far lower than 
values measured prior to the recovery period. In the blue mussel Mytilus edulis, significant recovery of DNA integrity has been also demonstrated in sperm following exposure to MMS,

331 suggesting that male gametes have a capacity for repair, albeit more limited than that of 332 somatic cells (Lewis and Galloway, 2009). The higher sensitivity of spermatozoa to 333 genotoxicants may be explained by the fact that they are particularly prone to oxidative stress, 334 as most of the cytoplasm containing antioxidant enzymes is released during spermiogenesis 335 (Aitken and Curry, 2010). This information could explain the presence of damage at all stages 336 of germ cells in males, which is not the case for females, also probably due to their higher 337 DNA repair capability (Ménézo et al., 2010). Indeed, the consequences of pollutant-induced 338 DNA damage in germ cells and gametes are directly dependent on the efficiency of DNA 339 repair mechanisms. Base excision repair (BER) is likely to be the main mechanism involved 340 in the enzymatic restoration of oxidative base lesions within the DNA. In humans, 341 spermatozoa have been found to have a very low ability to respond to such an attack, as they 342 only possess the first enzyme in the BER pathway: 8-oxoguanine glycosylase 1 (OGG1)

343 (Smith et al., 2013). If the oocyte fails to complete the post- fertilization repair process

344 properly, or if the repair machinery is inadequate to repair DNA damage, de novo mutations 345 in offspring are potentially created (Aitken et al., 2014).

346 Our immunohistochemistry analysis offered additional information. Cytoplasm was also 347 labelled in oogonia. The detection of 8-oxodGuo in this cell area could indicate the presence 348 of DNA damage in mitochondrial DNA. HPLC analysis was actually performed on whole 349 DNA extraction, including both genomic and mitochondrial DNA.

350 In addition to germ cells, intra-gonadal somatic cells (ISC) were also stained in males and 351 females. These cells have a crucial role on the structuring of germinal epithelium in gonadal 352 tubule. In male they possess some ultrastructural characteristics founded in vertebrate Sertoli 353 cells (Franco et al., 2011). Therefore, these properties make ISC ideal candidates as paracrine 
regulator of germ lineage development. DNA damage on these cells could have consequences

355 on gametogenesis progress.

356 Moreover, it is interesting to note that without RNase digestion, high immunolabelling was

357 observed in the cytoplasm of spermatogonia. This could indicate oxidized base presence in 358 RNA, which is likely more prone to oxidative damage than DNA for different reasons. RNA

359 is mainly single-stranded and more easily accessible to ROS. It has relatively less association

360 with proteins and an extensive sub-cellular distribution. Cytoplasmic RNA is in close

361 proximity to mitochondria where the majority of ROS is generated and up to now there is no

362 evidence of repair mechanisms of oxidatively-damaged RNA (Li et al., 2006). Oxidative

363 RNA damage could result in a loss or alteration of RNA function. In humans, evidence that

364 oxidized RNA is related to the pathogenesis of degenerative diseases is mounting (Kong and

365 Lin, 2010).

366 Conclusion

367 In this study, HPLC and immunohistochemical analysis allowed the detection of 8-oxodGuo

368 for the first time in gonads of the Pacific oyster. Diuron exposure resulted in oxidative DNA

369 damage in oyster reproductive tissue, probably due to the induction of oxidative stress. The

370 DNA damage revealed in germ cells explained the damage found in gametes of diuron-

371 exposed genitors in our previous study (Barranger et al, 2014), leading to the vertical

372 transmission of damaged genetic material to offspring. Male and female gonads both showed

373 high levels of 8-oxodGuo. However, sex differences were detected with regards to the number

374 and cell distribution of oxidized nucleosides. These differences need to be explored by

375 studying the various mechanisms in play - DNA repair, antioxidant defences and

376 biotransformation capacity - separately in males and females. An interesting and disturbing

377 find was the presence of oxidative DNA damage in early germ cells, suggesting a possible

378 long term effect on successive germ lines of the exposed animals. It would be useful to 
quantify the oxidized base 8-oxo dGuo in RNA after exposure to pesticides in a future study,

380 to assess whether RNA, as well as DNA, can be damaged. Our results demonstrate the 381 significant impact of chemical pollution and especially pesticides on reproduction of the 382 Pacific oyster.

\section{Acknowledgments}

385 This work was funded by the French National Research Agency (ANR-CESA-01601). The authors are grateful to Myriam Robard from Cellular and Tissular Imaging Core Facility of

Nantes University (MicroPICell) for her help in the first microscopic observations of the slides.

\section{References}

Aitken, R.J., Curry, B.J., 2010. Redox Regulation of Human Sperm Function: From the Physiological Control of Sperm Capacitation to the Etiology of Infertility and DNA Damage in the Germ Line. Antioxid. Redox Signal. 14, 367-381. doi:10.1089/ars.2010.3186

Aitken, R.J., Smith, T.B., Jobling, M.S., Baker, M. a, De Iuliis, G.N., 2014. Oxidative stress and male

Akcha, F., Burgeot, T., Budzinski, H., Pfohl-Leszkowicz, a, Narbonne, J., 2000a. Induction and elimination of bulky benzo[a]pyrene-related DNA adducts and 8-oxodGuo in mussels Mytilus galloprovincialis exposed in vivo to B[a]P-contaminated feed. Mar. Ecol. Prog. Ser. 205, 195-206. doi:10.3354/meps205195

Akcha, F., Riuz, S., Zampieron, C., Venier, P., Burgeot, T., Cadet, J., Narbonne, J.F., 2000 b.

Akcha, F., Spagnol, C., Rouxel, J., 2012. Genotoxicity of diuron and glyphosate in oyster spermatozoa

Almeida, E. a., Bainy, A.C.D., Dafre, A.L., Gomes, O.F., Medeiros, M.H.G., Di Mascio, P., 2005. Oxidative stress in digestive gland and gill of the brown mussel (Perna perna) exposed to air and re-submersed. J. Exp. Mar. Bio. Ecol. 318, 21-30. doi:10.1016/j.jembe.2004.12.007

Aloisio Torres, M., Pires Testa, C., Gáspari, C., Beatriz Masutti, M., Maria Neves Panitz, C., CuriPedrosa, R., Alves de Almeida, E., Di Mascio, P., Wilhelm Filho, D., 2002. Oxidative stress in the mussel Mytella guyanensis from polluted mangroves on Santa Catarina Island, Brazil. Mar. Pollut. Bull. 44, 923-932. doi:10.1016/S0025-326X(02)00142-X 
Alves de Almeida, E., Celso Dias Bainy, A., Paula de Melo Loureiro, A., Regina Martinez, G., Miyamoto, S., Onuki, J., Fujita Barbosa, L., Carrião Machado Garcia, C., Manso Prado, F., Eliza Ronsein, G., Alexandre Sigolo, C., Barbosa Brochini, C., Maria Gracioso Martins, A., Helena Gennari de Medeiros, M., Di Mascio, P., 2007. Oxidative stress in Perna perna and other bivalves as indicators of environmental stress in the Brazilian marine environment: antioxidants, lipid peroxidation and DNA damage. Comp. Biochem. Physiol. A. Mol. Integr. Physiol. 146, 588-600. doi:10.1016/j.cbpa.2006.02.040

Barahona-Gomariz, M. V, Sanz-Barrera, F., Sánchez-Fortún, S., 1994. Acute toxicity of organic solvents on Artemia salina. Bull. Environ. Contam. Toxicol. 52, 766-71.

Barranger, A., Akcha, F., Rouxel, J., Brizard, R., Maurouard, E., Pallud, M., Menard, D., Tapie, N., Budzinski, H., Burgeot, T., Benabdelmouna, A., 2014. Study of genetic damage in the Japanese oyster induced by an environmentally-relevant exposure to diuron: Evidence of vertical transmission of DNA damage. Aquat. Toxicol. 146, 93-104. doi:10.1016/j.aquatox.2013.10.032

Barranger, A., Benabdelmouna, A., Dégremont, L., Burgeot, T., Akcha, F., 2015. Parental exposure to environmental concentrations of diuron leads to aneuploidy in embryos of the Pacific oyster, as evidenced by fluorescent in situ hybridization. Aquat. Toxicol. 159, 36-43. doi:10.1016/j.aquatox.2014.11.011

Bouilly, K., Bonnard, M., Gagnaire, B., Renault, T., Lapègue, S., 2007. Impact of diuron on aneuploidy and hemocyte parameters in Pacific oyster, Crassostrea gigas. Arch. Environ. Contam. Toxicol. 52, 58-63. doi:10.1007/s00244-005-0256-8

Bouilly, K., Leitão, A., McCombie, H., Lapègue, S., 2003. Impact of atrazine on aneuploidy in pacific oysters, Crassostrea gigas. Environ. Toxicol. Chem. 22, 219-23.

Brunelli, E., Domanico, F., La Russa, D., Pellegrino, D., 2014. Sex differences in oxidative stress biomarkers. Curr. Drug Targets 15, 811-5.

Buisson, S., Bouchart, V., Guerlet, E., Malas, J.P., Costil, K., 2008. Level of contamination and impact of pesticides in cupped oyster, Crassostrea gigas, reared in a shellfish production area in Normandy (France). J. Environ. Sci. Health. B. 43, 655-64. doi:10.1080/03601230802352732

Burgeot, T., Gagnaire, B., Renault, T., Haure, J., Moraga, D., David, E., Boutet, I., Sauriau, P.., Malet, N., Bouchet, V., Le Roux, A., Lapègue, S., Bouilly, K., Le Moullac, G., Arzul, G., Knoery, J., Quiniou, F., Bacher, C., Soletchnick, P., 2008. Oyster summer morality risks associated with environmental stress., in: Samain, J.F., McCom- Bie, H. (Eds.), Summer Mortality of Pacific Oyster Crassostrea Gigas. The Morest Project. Éd. Ifremer/Quæ. pp. 107-151.

Canova, S., Degan, P., Peters, L.., Livingstone, D.., Voltan, R., Venier, P., 1998. Tissue dose, DNA adducts, oxidative DNA damage and CYP1A-immunopositive proteins in mussels exposed to waterborne benzo[a]pyrene. Mutat. Res. Mol. Mech. Mutagen. 399, 17-30. doi:10.1016/S00275107(97)00263-7

Caquet, T., Roucaute, M., Mazzella, N., Delmas, F., Madigou, C., Farcy, E., Burgeot, T., Allenou, J.P., Gabellec, R., 2013. Risk assessment of herbicides and booster biocides along estuarine continuums in the Bay of Vilaine area (Brittany, France). Environ. Sci. Pollut. Res. 20, 651-666. biomarkers, malondialdehyde and 8-oxo-7,8-dihydro-2'-deoxyguanosine, in the freshwater 
bivalve Unio tumidus. Sci. Total Environ. 322, 109-22. doi:10.1016/j.scitotenv.2003.09.028

Dégremont, L., Boudry, P., Ropert, M., Samain, J.-F., Bédier, E., Soletchnik, P., 2010. Effects of age and environment on survival of summer mortality by two selected groups of the Pacific oyster Crassostrea gigas. Aquaculture 299, 44-50. doi:10.1016/j.aquaculture.2009.12.009

Evans, M.D., Dizdaroglu, M., Cooke, M.S., 2004. Oxidative DNA damage and disease: induction, repair and significance., Mutation research. doi:10.1016/j.mrrev.2003.11.001

FAO, 2014. Global Aquaculture Production 1950-2012 - http://www.fao.org/fishery/statistics/globalaquaculture-production/en.

Figueiredo-Fernandes, a., Fontaínhas-Fernandes, a., Peixoto, F., Rocha, E., Reis-Henriques, M. a., 2006. Effects of gender and temperature on oxidative stress enzymes in Nile tilapia Oreochromis niloticus exposed to paraquat. Pestic. Biochem. Physiol. 85, 97-103. doi:10.1016/j.pestbp.2005.11.001

Franco, A., Heude Berthelin, C., Goux, D., Sourdaine, P., Mathieu, M., 2008. Fine structure of the early stages of spermatogenesis in the Pacific oyster, Crassostrea gigas (Mollusca, Bivalvia). Tissue Cell 40, 251-260. doi:10.1016/j.tice.2007.12.006

Franco, A., Jouaux, A., Mathieu, M., Sourdaine, P., Lelong, C., Kellner, K., Heude Berthelin, C., 2010. Proliferating cell nuclear antigen in gonad and associated storage tissue of the Pacific oyster Crassostrea gigas : seasonal immunodetection and expression in laser microdissected tissues. Cell Tissue Res. 340, 201-210. doi:10.1007/s00441-009-0923-6

Franco, A., Kellner, K., Goux, D., Mathieu, M., Heude Berthelin, C., 2011. Intragonadal somatic cells (ISCs) in the male oyster Crassostrea gigas: morphology and contribution in germinal epithelium structure. Micron 42, 718-25. doi:10.1016/j.micron.2011.04.003

Gabe, M., 1968. Techniques histologiques. 6th ed., Masson Cie, Paris,.

Gagnaire, B., Gay, M., Huvet, A., Daniel, J.-Y., Saulnier, D., Renault, T., 2007. Combination of a pesticide exposure and a bacterial challenge: in vivo effects on immune response of Pacific oyster, Crassostrea gigas (Thunberg). Aquat. Toxicol. 84, 92-102. doi:10.1016/j.aquatox.2007.06.002

Grizel, H., Héral, M., 1991. Introduction into France of the Japanese oyster (Crassostrea gigas). J. du Cons. / Cons. Perm. Int. pour l'Exploration la Mer 399-403.

Halliwell, B., Aruoma, O.I., 1991. DNA damage by oxygen-derived species. Febs 281, 9-19. doi:10.1016/0014-5793(91)80347-6

Helbock, H.J., Beckman, K.B., Shigenaga, M.K., Walter, P.B., Woodall, a a, Yeo, H.C., Ames, B.N., 1998. DNA oxidation matters: the HPLC-electrochemical detection assay of 8-oxodeoxyguanosine and 8-oxo-guanine. Proc. Natl. Acad. Sci. U. S. A. 95, 288-293. doi:10.1073/pnas.95.1.288

Heude-Berthelin, C., Laisney, J., Espinosa, J., Martin, O., Hernandez, G., Mathieu, M., Kellner, K., 2001. Storage and reproductive strategy in Crassostrea gigas from two different growing areas (Normandy and the Atlantic coast, France). Invertebr. Reprod. Dev. 40, 79-86.

His, É., Seaman, M., 1993. Effects of twelve pesticides on larvae of oysters (Crassostrea gigas) and on two species of unicellular marine algae (Isochrysis galbana and Chaetoceros calcitrans). CIEM- 
Huvet, A., Normand, J., Fleury, E., Quillien, V., Fabioux, C., Boudry, P., 2010. Reproductive effort of Pacific oysters: A trait associated with susceptibility to summer mortality. Aquaculture 304, 9599. doi:10.1016/j.aquaculture.2010.03.022

Kamhieh-milz, J., Salama, A., 2014. Oxidative Stress Is Predominant in Female but Not in Male Patients with Autoimmune Thrombocytopenia. Oxid. Med. Cell. Longev. 2014, 1-9.

Kirankumar, B., Guruprasad, B.K., Santoshkumar, M., Anand, S.N., Karegoudar, T.B., 2013. The response of Paracoccus sp. SKG to acetonitrile-induced oxidative stress. Extremophiles 17, 10371044. doi:10.1007/s00792-013-0585-x

Köck, M., Farré, M., Martínez, E., Gajda-Schrantz, K., Ginebreda, A., Navarro, A., Alda, M.L. De, Barceló, D., 2010. Integrated ecotoxicological and chemical approach for the assessment of pesticide pollution in the Ebro River delta (Spain). J. Hydrol. 383, 73-82. doi:10.1016/j.jhydrol.2009.12.029

Kong, Q., Lin, C.-L.G., 2010. Oxidative damage to RNA: mechanisms, consequences, and diseases. Cell. Mol. Life Sci. 67, 1817-29. doi:10.1007/s00018-010-0277-y

Lacaze, E., Geffard, O., Goyet, D., Bony, S., Devaux, A., 2011. Linking genotoxic responses in Gammarus fossarum germ cells with reproduction impairment, using the Comet assay. Environ. Res. 111, 626-634. doi:10.1016/j.envres.2011.03.012

Lemiere, S., Cossu-Leguille, C., Charissou, A.-M., Vasseur, P., 2005. DNA damage (comet assay) and 8-oxodGuo (HPLC-EC) in relation to oxidative stress in the freshwater bivalve Unio tumidus. Biomarkers 10, 41-57. doi:10.1080/13547500500038783

Lewis, C., Galloway, T., 2009. Reproductive consequences of paternal genotoxin exposure in marine invertebrates. Environ. Sci. Technol. 43, 928-33.

Li, Z., Wu, J., Deleo, C.J., 2006. RNA damage and surveillance under oxidative stress. IUBMB Life 58, 581-8. doi:10.1080/15216540600946456

Luna-Acosta, A., Renault, T., Thomas-Guyon, H., Faury, N., Saulnier, D., Budzinski, H., Le Menach, K., Pardon, P., Fruitier-Arnaudin, I., Bustamante, P., 2012. Detection of early effects of a single herbicide (diuron) and a mix of herbicides and pharmaceuticals (diuron, isoproturon, ibuprofen) on immunological parameters of Pacific oyster (Crassostrea gigas) spat. Chemosphere 87, 133540. doi:10.1016/j.chemosphere.2012.02.022

Lushchak, V.I., 2011. Environmentally induced oxidative stress in aquatic animals. Aquat. Toxicol. 101, 13-30. doi:10.1016/j.aquatox.2010.10.006

Mai, H., Cachot, J., Brune, J., Geffard, O., Belles, A., Budzinski, H., Morin, B., 2012. Embryotoxic and genotoxic effects of heavy metals and pesticides on early life stages of Pacific oyster (Crassostrea gigas). Mar. Pollut. Bull. 64, 2663-70. doi:10.1016/j.marpolbul.2012.10.009

Ménézo, Y., Dale, B., Cohen, M., 2010. DNA damage and repair in human oocytes and embryos: a review. Zygote 18, 357-65. doi:10.1017/S0967199410000286

Mottier, A., Séguin, A., Devos, A., Pabic, C. Le, Voiseux, C., Lebel, J.M., Serpentini, A., Fievet, B., Costil, K., 2014. Effects of subchronic exposure to glyphosate in juvenile oysters (Crassostrea 
gigas): From molecular to individual levels. Mar. Pollut. Bull. doi:10.1016/j.marpolbul.2014.10.026

Munaron, D., 2004. Étude des apports en herbicides et en nutriments par la Charente : Modélisation de la dispersion de l'atrazine dans le bassin de Marennes-Oléron. Université Paris 6 Pierre et Marie Curie.

Munaron, D., Tapie, N., Budzinski, H., Andral, B., Gonzalez, J.-L., 2012. Pharmaceuticals, alkylphenols and pesticides in Mediterranean coastal waters: Results from a pilot survey using passive samplers. Estuar. Coast. Shelf Sci. 114, 82-92. doi:10.1016/j.ecss.2011.09.009

Ochoa, V., Riva, C., Faria, M., Köck-Schulmeyer, M., de Alda, M.L., Barceló, D., Fernandez Tejedor, M., Roque, A., Ginebreda, A., Barata, C., 2012. Are pesticide residues associated to rice production affecting oyster production in Delta del Ebro, NE Spain? Sci. Total Environ. 437, 209 18. doi:10.1016/j.scitotenv.2012.07.058

Renault, T., Le Deuff, R.M., Cochennec, N., Maffart, P., 1994. Herpesviruses associated with mortalities among Pacific oyster, Crassostrea gigas, in France - Comparative study. Rev. Médicale Vétérinaire $145,735-742$.

Samain, J.-F., McCombie, H., 2008. Summer mortality of Pacific oyster Crassostrea gigas: the Morest Project. Editions Quae.

Shibutani, S., Takeshita, M., Grollman, A.P., 1991. Insertion of specific bases during DNA synthesis past the oxidation-damaged base 8-oxodG. Nature 349, 431-434.

Sies, H., 1993. Strategies of antioxidant defense, in: EJB Reviews 1993 SE - 9, EJB Reviews. Springer Berlin Heidelberg, pp. 101-107. doi:10.1007/978-3-642-78757-7_9

Smith, T.B., Dun, M.D., Smith, N.D., Curry, B.J., Connaughton, H.S., Aitken, R.J., 2013. The presence of a truncated base excision repair pathway in human spermatozoa that is mediated by OGG1. J. Cell Sci. 126, 1488-97. doi:10.1242/jcs.121657

SoeS - Service de l'Observation et des Statistiques, 2013. Contamination des cours d'eau par les pesticides en 2011. http://www.developpement-durable.gouv.fr/IMG/pdf/CS436.pdf.

Soletchnik, P., Bouchet, V., Malestroit, P., Seugnet, L., Blouin, F., Radford-knoery, J., Burgeot, T., Sauriau, P.-G., 2005. Mortalité de Crassostrea gigas dans le bassin de Marennes Oléron. Etude physico chimique du sédiment. Etude du modèle de mortalité "plat-table" de C. gigas dans le bassin de Marennes Oléron. Etude "Dynamo" du projet MOREST.

The Official Journal of the French Republic - bylaw 21 August, 2008, Arrêté du 21 août 2008 concernant l'interdiction d'utilisation de certains produits biocides http://www.legifrance.gouv.fr/affichTexte.do?cidTexte=JORFTEXT000019375714.

The Official Journal of the French Republic - no. 204 September 4, 2007, Avis aux fabricants, Biocides in the UK Coastal Environment and Potential Risks of Biological Effects. Mar. Pollut. Bull. 42, 677-688. 
571 Wang, L.-S., Wang, L., Wang, L., Wang, G., Li, Z.-H., Wang, J.-J., 2009. Effect of 1-butyl-3572 methylimidazolium tetrafluoroborate on the wheat (Triticum aestivum L.) seedlings. Environ. $573 \quad$ Toxicol. 24, 296-303. doi:10.1002/tox

574

575 


\section{Legends}

577 Figure 1: 8-oxodGuo levels in male (A) and female (B) gonads. Data marked with different 578 letters differed significantly $(\mathrm{p}<0.05)$.

579 Figure 2: Control slides. Control slide without primary antibodies in male gonad (A) and 580 control slide without secondary antibodies in female gonad (B). Sections show no specific 581 labeling. Immunohistological detection of 8-oxodGuo in male gonadal tubule without RNase 582 (C) and with RNase (D). Without RNase staining is detected around nuclei of spermatogonia

583 Figure 3: Immunohistological detection of 8-oxodGuo in male gonadal tubule of Crassostrea 584 gigas. Different views of male gonadal tubule (A, B, C, D), showing labelled spermatogonia 585 (A, B, C, D); spermatids (C), intragonadal somatic cells (B), haemocytes (A, D) and interstitial 586 conjunctive cells (B). sg I: spermatogonium I, sg II: spermatogonium II, sp: spermatid, sz: 587 588 spermatozoid, isc: intragonadal somatic cell, h: haemocyte, cc: interstitial conjunctive cell.

Figure 4: Immunohistological detection of 8-oxodGuo in female gonadal tubule of Crassostrea gigas, showing the presence of 8-oxodGuo in nuclei, nucleoli and cytoplasm of oogonia $(A, B, C)$, in putative germ stem cells $(B)$, in intragonadal somatic cells $(C, D, E)$, interstitial conjunctive cells $(C)$ but not in oocytes $(D, E)$. og: oogonia, o: oocyte, n: nucleus, nu: nucleolus, cyt: cytoplasm, pGSC: putative germ stem cells, isc: intragonadal somatic cell, cc: interstitial conjunctive cells. 


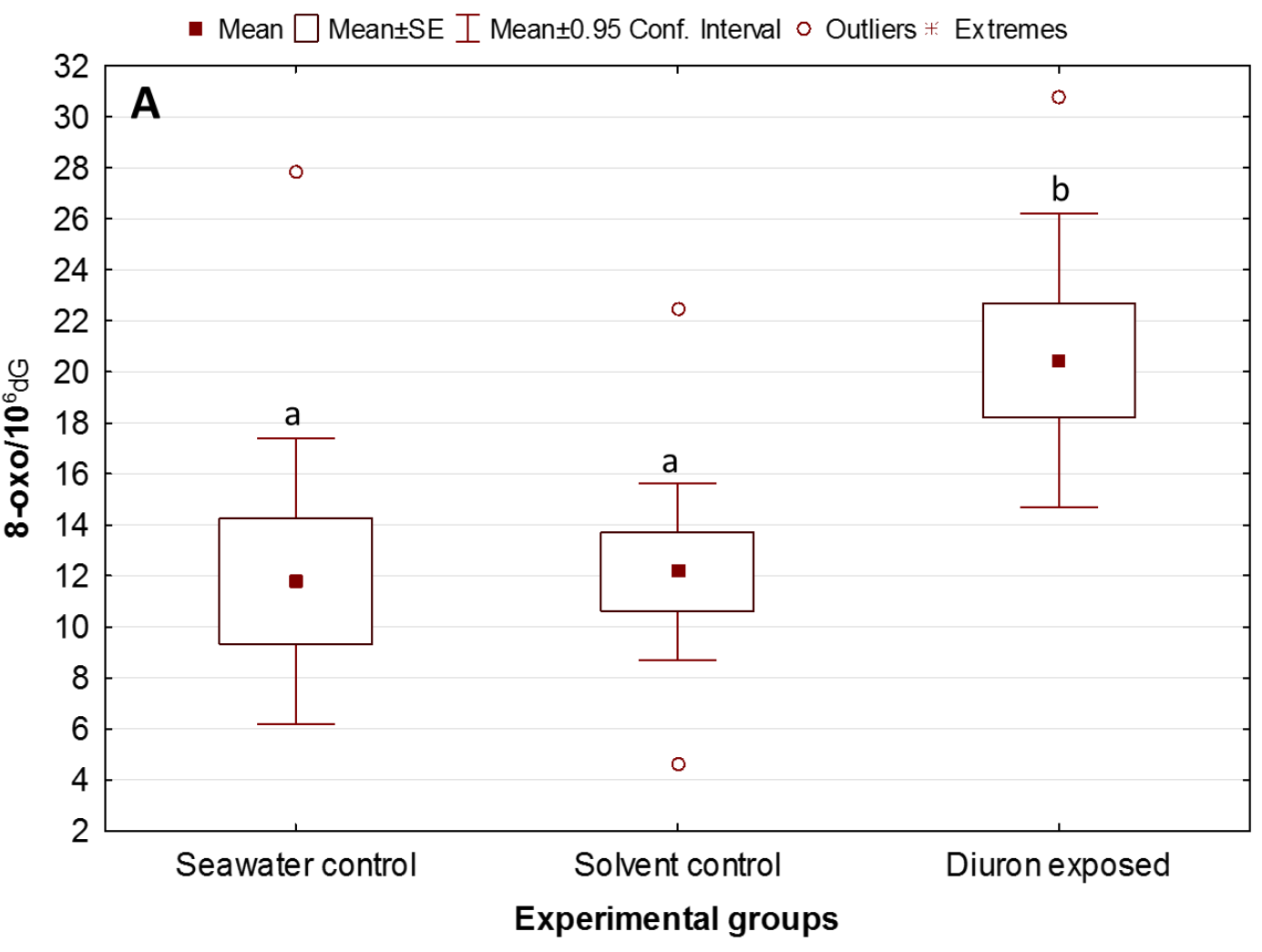

599

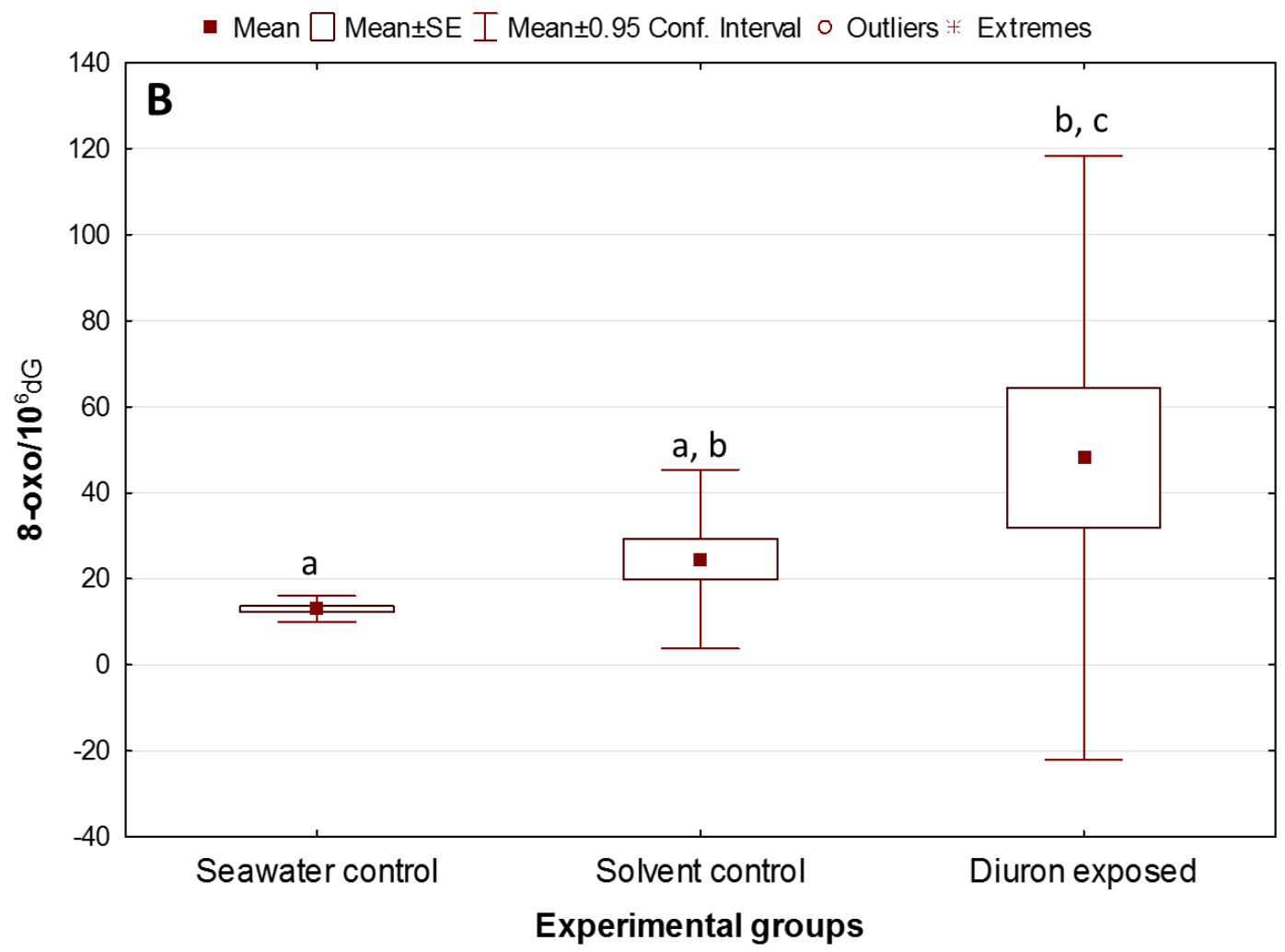

600 
$602 \quad$ Figure 2
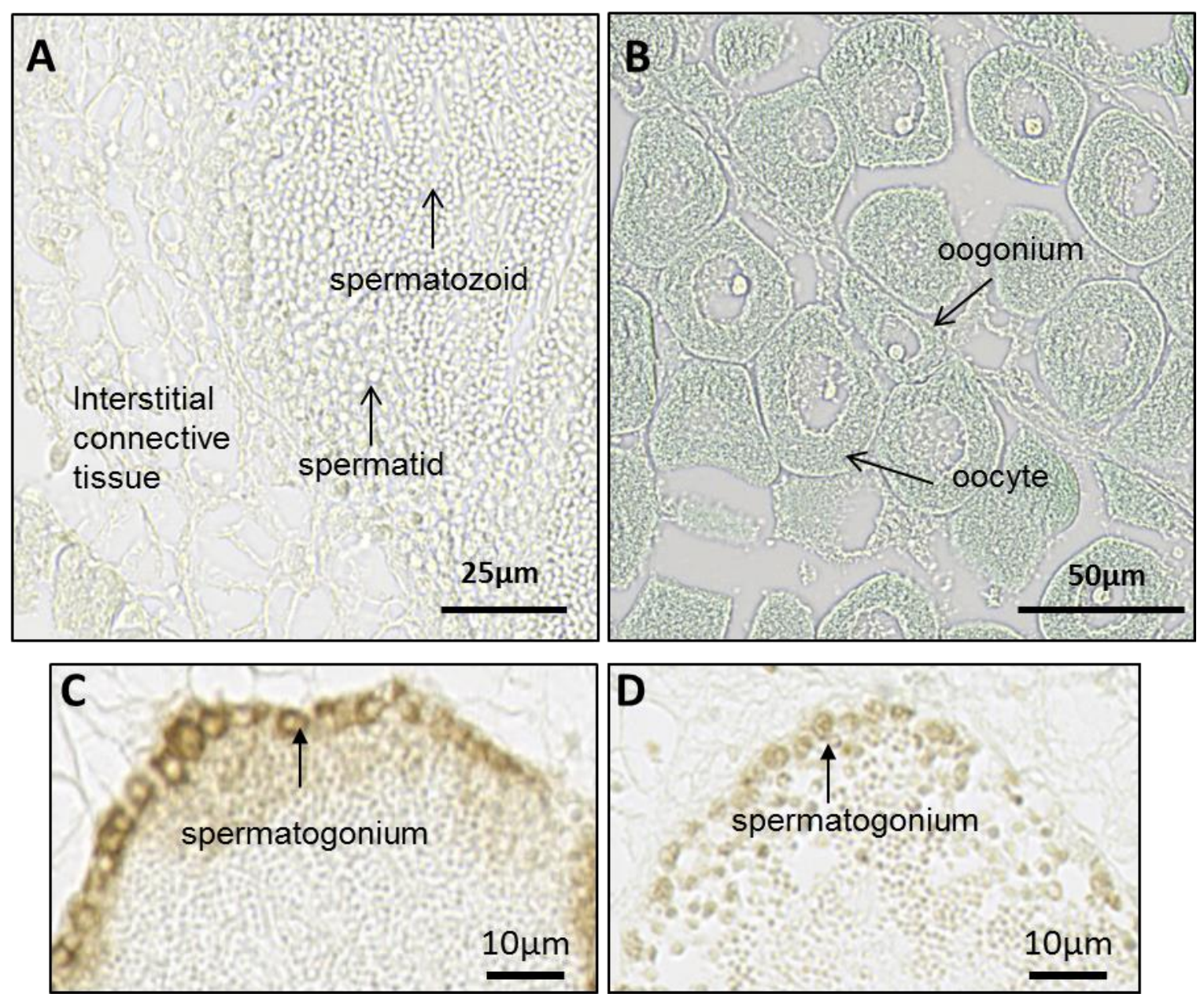

603

604

605 


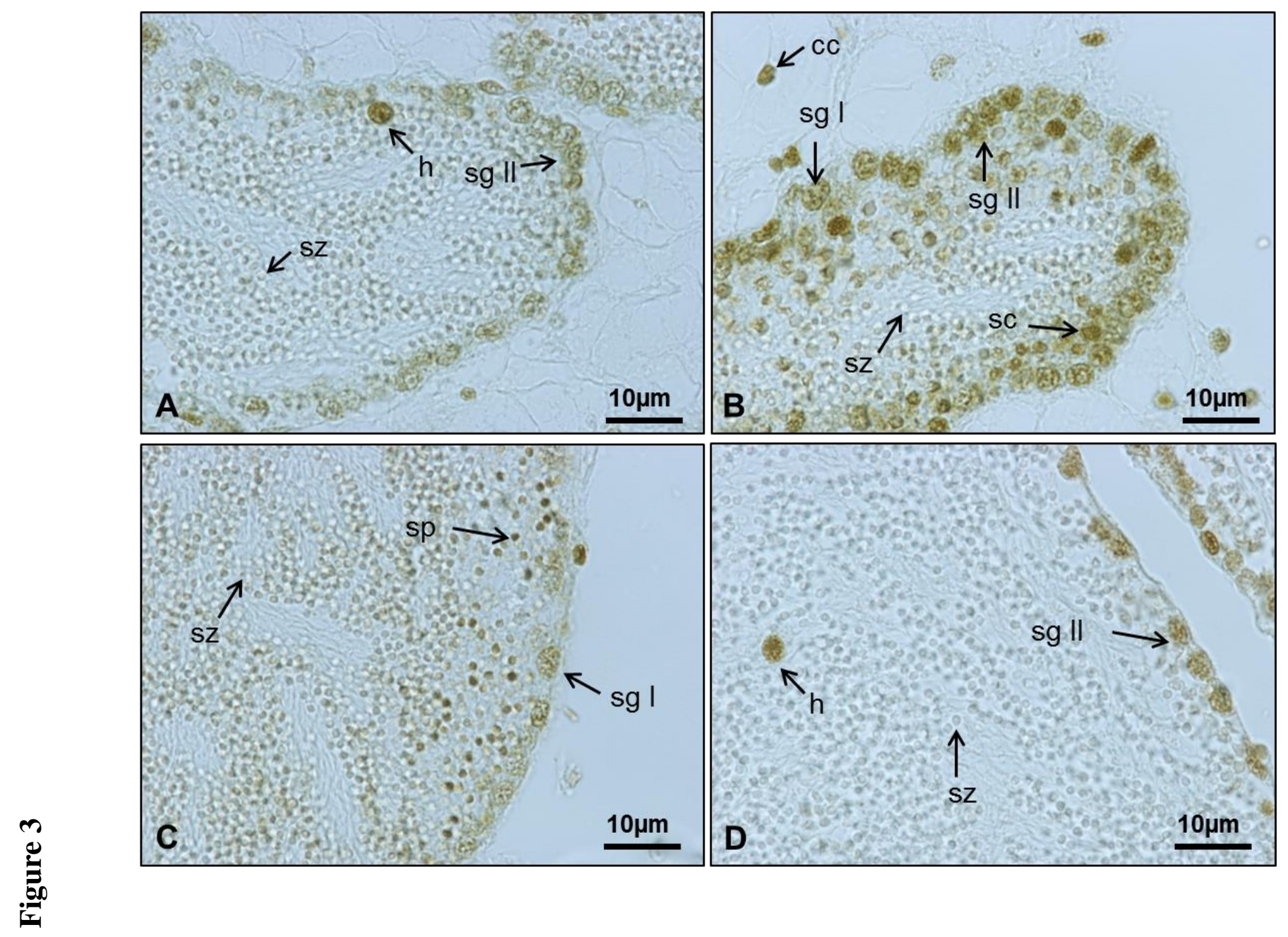


$610 \quad$ Figure 4
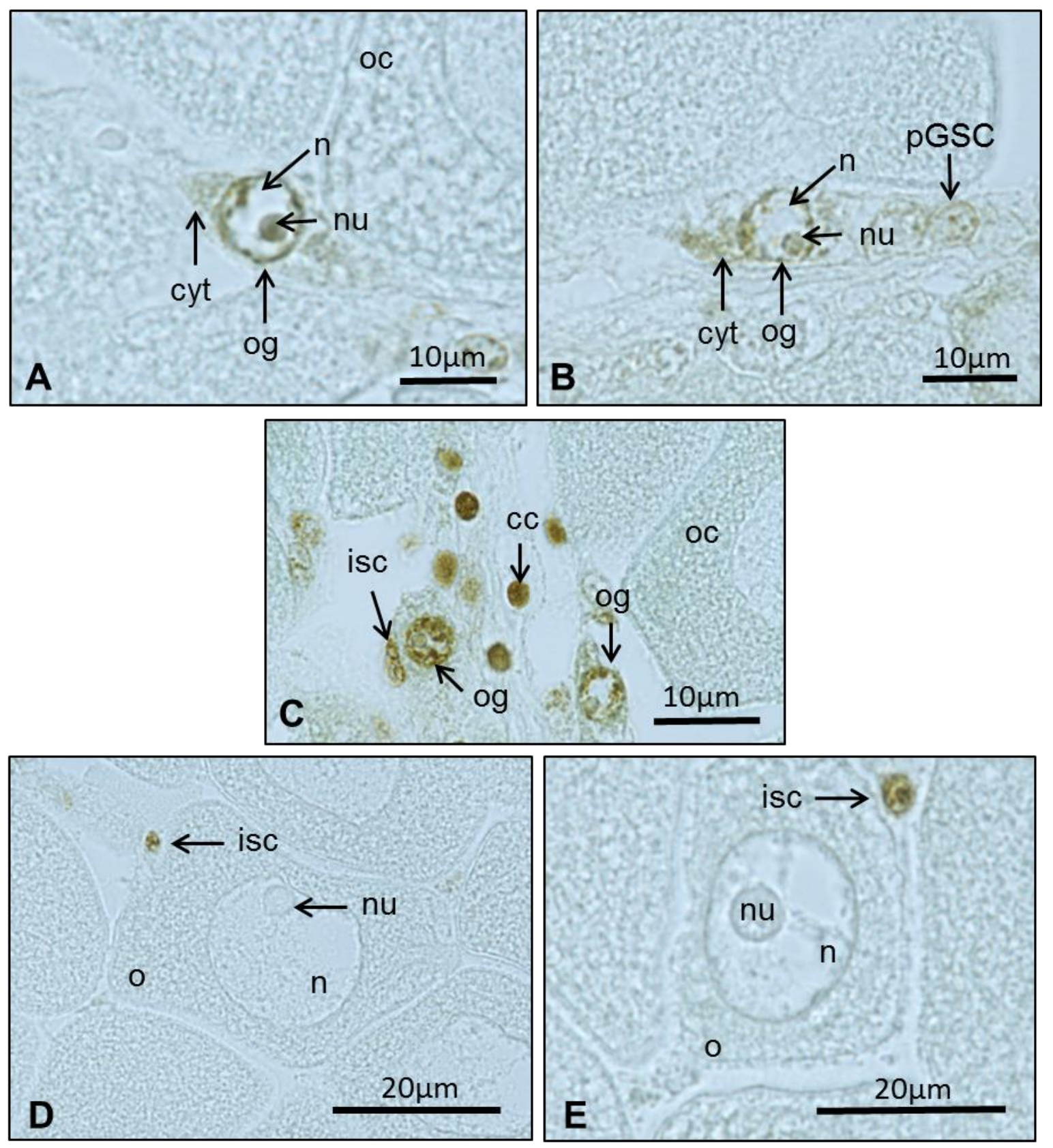

611

612

613 